\title{
Impacts of Two-Type ENSO on Rainfall over Taiwan
}

\author{
Chen-Chih Lin, Yi-Jiun Liou, and Shih-Jen Huang \\ Department of Marine Environmental Informatics, National Taiwan Ocean University, Keelung 20224, Taiwan \\ Correspondence should be addressed to Chen-Chih Lin; mikania.lin@gmail.com
}

Received 14 October 2014; Revised 13 January 2015; Accepted 13 January 2015

Academic Editor: Yuri Kuleshov

Copyright (C) 2015 Chen-Chih Lin et al. This is an open access article distributed under the Creative Commons Attribution License, which permits unrestricted use, distribution, and reproduction in any medium, provided the original work is properly cited.

\begin{abstract}
Impacts of two-type ENSO (El Niño/Southern Oscillation), canonical ENSO and ENSO Modoki, on rainfall over Taiwan are investigated by the monthly mean rainfall data accessed from Taiwan Central Weather Bureau. The periods of the two-type ENSO are distinguished by Niño 3.4 index and ENSO Modoki index (EMI). The rainfall data in variously geographical regions are analyzed with the values of Niño 3.4 and EMI by correlation method. Results show that the seasonal rainfalls over Taiwan are different depending on the effects of two-type ENSO. In canonical El Niño episode, the rainfall increases in winter and spring while it reduces in summer and autumn. On the contrary, the rainfall increases in summer and autumn but reduces in winter and spring in El Niño Modoki episode. Nevertheless, two types of La Niña cause similar effects on the rainfall over Taiwan. It increases in autumn only. The rainfall variations in different types of ENSO are mainly caused by the monsoon and topography.
\end{abstract}

\section{Introduction}

El Niño and La Niña events are the phenomenon of interannual scale interactions between atmosphere and ocean [1]. During El Niño episodes, lower than normal pressure is over the eastern tropical Pacific and higher than normal pressure is over Indonesia and northern Australia. The air-pressure oscillation swings between east and west getting associated with the weaker than normal near-surface equatorial easterly winds. The normal patterns of tropical precipitation and atmospheric circulation become disrupted. The abnormally warm waters rise up and aggregate cloudiness to cause rainfall in the eastern and equatorial central Pacific [2, 3]. Meanwhile, rainfall has diminished over Indonesia, Malaysia, and northern Australia. Sometimes a totally reversed phenomenon can be observed after El Niño episode, that is, La Niña episode. The phenomenon caused by the atmospheric pressure oscillation between the east and west tropical South Pacific is called El Niño/Southern Oscillation (ENSO) [4].

Recent studies have shown the distinct warming and cooling patterns different from those of canonical El Niño events. A warm anomaly arises in the central Pacific whereas cold anomalies are on both flanks of the basin. The new phenomenon is of interest to the climate community which is called El Niño Modoki $[5,6]$. It is also known as central Pacific
El Niño [7] or warm pool El Niño [8]. La Niña Modoki is named as colder central Pacific is flanked by warmer eastern and western Pacific [9]. Both phenomena are referred to as ENSO Modoki. Compared to canonical ENSO, ENSO Modoki has become more prominent in recent times, thereby changing the teleconnection pattern arising from the tropical Pacific [10]. The occurrences of anomalous warm water may cause changes in air pressure, precipitation, and wind field $[7,11,12]$. The generation mechanism may significantly be affected by atmospheric forcing rather than by basin-wide thermocline variations $[8,13]$.

In response to rainfall variation, ENSO episodes have been detected in numerous studies. Trenberth and Caron [14] described the decrease of rainfall over the northeast coast of Brazil but increase over the southern Brazil and the Indian Ocean. During the mature period of El Niño, the anticyclone runs over the East Asia and enhances the rainfall in southern China [15]. Weng et al. [16] pointed out that El Niño Modoki and its climate impacts are very different from those of canonical El Niño. During the El Niño Modoki episode, a wet region is in the central Pacific where it is dry during the El Niño episode. An El Niño Modoki may also cause a shorter and more intense Australian monsoon precipitation [17]. Cai and Cowan [18] demonstrated that the La Niña Modoki is effective in causing an autumn rainfall increase 


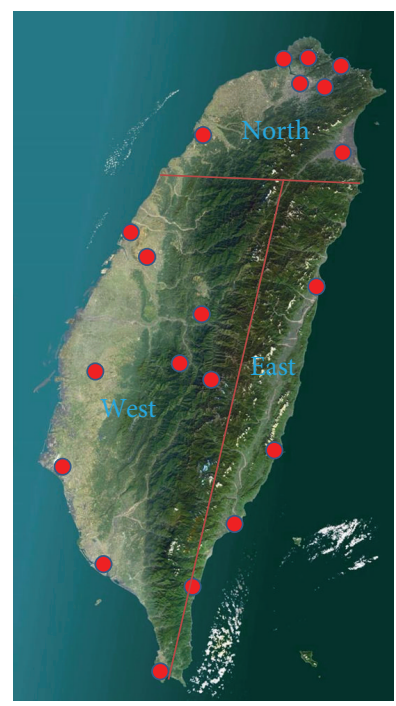

Figure 1: Points indicate the rain stations over Taiwan used in this study. The study area is separated into 3 regions: north, west, and east.

over northwestern Australia rather than over the east as in a canonical La Niña because convection shifts westward. Feng and $\mathrm{Li}$ [19] also mentioned that the precipitation increases in spring over the southern China during the canonical El Niño, while it decreases during the El Niño Modoki. A similar feature is also found in southwest America. The precipitation increases in autumn during the canonical El Niño, but it decreases during the El Niño Modoki [20]. The canonical ENSO and ENSO Modoki may affect the rainfall in the Pacific but also telecommunicate to other areas. Somehow, the effects of two-type ENSO on rainfall over Taiwan are not clearly analyzed. Thus, it is necessary to document systematically how they affect Taiwan.

\section{Materials and Methods}

Taiwan is a subtropical island located in the latitudes between $22^{\circ} \mathrm{N}$ and $26^{\circ} \mathrm{N}$ to the southeast of China. The Central Mountain Range with an average elevation of $2000 \mathrm{~m}$ runs from the north to the south and separates east and west to two different ecoregions. Yen and Chen [21] pointed out that the rainfall over Taiwan is mainly dominated by the seasonal monsoon, northeasterly in winter and southwesterly in summer, as well as modified by the local topography. To study the effect of ENSO on rainfall over Taiwan, we accessed the data from the Data Bank for Atmospheric Research, Taiwan Typhoon and Flood Research Institute, collected by Taiwan Central Weather Bureau. The rainfall data span from 1980 to 2011 at 20 stations in Taiwan as shown in Figure 1 has been employed in this study. Because the topography is very complicated in Taiwan, the weather stations distribute from $5 \mathrm{~m}$ elevation to over than $3000 \mathrm{~m}$. Therefore, rainfall amount is localized. To avoid the local effect, we grouped the weather stations and then divided them into six subareas according to the terrain of Taiwan. The subareas include north, west, and east regions. Each region is further separated into plain and mountain. Because there is no rain station on the eastern mountain subarea that we have a total of five subareas for this study. Table 1 presents the rain stations in each subarea.

Since the rainfall over Taiwan is mostly affected by monsoon, we ignore the regular season division of four seasons: spring from March to May, summer from June to August, autumn from September to November, and winter from December to February in most previous studies [5, $18,19,22,23]$. Instead, we consider monsoon gradually increases from November to December, while stands in January and February. Therefore, we divide the rainy periods with bimonthly as spring rain from March to April, Meiyu from May to June, summer rain from July to August, autumn rain from September to October, early winter rain from November to December, and winter rain from January to February. This division of rainy season is similar to Wang et al. [24] classifying the whole year to five periods: spring rain period (March and April), Meiyu period (May and June), summer rain period (July, August, and September), autumn rain period (October and November), and winter rain period (December, January, and February). Here, we consider the rainy season classified in more detail. In data process, the rainfall data in each station is subtracted by its mean value from 1980 to 2011, as anomaly data. A 3-month running mean filter is then applied to remove high frequent variability.

To distinguish the years of El Niño, La Niña, El Niño Modoki, and La Niña Modoki, the Niño 3.4 index and the El Niño Modoki index (EMI) are applied to this study. A 3month running mean of sea surface temperature anomaly (SSTA) at the region of $5^{\circ} \mathrm{S}-5^{\circ} \mathrm{N}, 170^{\circ} \mathrm{W}-120^{\circ} \mathrm{W}$ has been characterized as the Niño 3.4 index. The EMI is the combination of area average of SSTA at regions A $\left(10^{\circ} \mathrm{S}-10^{\circ} \mathrm{N}\right.$, $\left.165^{\circ} \mathrm{E}-140^{\circ} \mathrm{W}\right), \mathrm{B}\left(15^{\circ} \mathrm{S}-5^{\circ} \mathrm{N}, 110^{\circ} \mathrm{W}-70^{\circ} \mathrm{W}\right)$, and $\mathrm{C}\left(10^{\circ} \mathrm{S}-\right.$ $\left.20^{\circ} \mathrm{N}, 125^{\circ} \mathrm{E}-145^{\circ} \mathrm{E}\right)$, respectively, as shown in Figure 2 and is defined as [5]

$$
\mathrm{EMI}=[\mathrm{SSTA}]_{\mathrm{A}}-0.5 \times[\mathrm{SSTA}]_{\mathrm{B}}-0.5 \times[\mathrm{SSTA}]_{\mathrm{C}} \cdot
$$

The value of Niño 3.4 lager than or equal to 0.45 is considered as the canonical El Niño episode, while the value smaller than or equal to -0.45 is considered as the canonical La Niña episode. The same value is applied to EMI. The EMI value lager than or equal to 0.45 is considered as the El Niño Modoki, while smaller than or equal to -0.45 is considered as the La Niña Modoki. We compute the correlation coefficient between rainfall anomaly and both ENSO indices. The positive correlation coefficient means rainfall increasing associates with positive ENSO indices (i.e., El Niño event), or the decreasing rainfall associates with negative ENSO indices (i.e., La Niña event). On the contrary, the negative correlation coefficient means rainfall decreasing associates with positive ENSO indices, or rainfall increasing associates with negative ENSO indices.

\section{Results and Discussion}

3.1. Influences during Canonical El Niño Episode. Figure 4 shows correlation coefficients between rainfall anomaly and Niño 3.4 at five subareas in different rainy periods. In spring 
TABLE 1: Information of rain stations in this study.

\begin{tabular}{|c|c|c|c|c|c|}
\hline & Subarea & Station name & Height above sea level (m) & Latitude & Longitude \\
\hline \multirow{7}{*}{ North } & \multirow{5}{*}{ Plain } & Tamsui & 19.0 & $121^{\circ} 26^{\prime} 24^{\prime \prime} \mathrm{E}$ & $25^{\circ} 09^{\prime} 56^{\prime \prime} \mathrm{N}$ \\
\hline & & Taipei & 5.3 & $121^{\circ} 30^{\prime} 24^{\prime \prime} \mathrm{E}$ & $25^{\circ} 02^{\prime} 23^{\prime \prime} \mathrm{N}$ \\
\hline & & Keelung & 26.7 & $121^{\circ} 43^{\prime} 56^{\prime \prime} \mathrm{E}$ & $25^{\circ} 08^{\prime} 05^{\prime \prime} \mathrm{N}$ \\
\hline & & Yilan & 7.2 & $121^{\circ} 44^{\prime} 53^{\prime \prime} \mathrm{E}$ & $24^{\circ} 45^{\prime} 56^{\prime \prime} \mathrm{N}$ \\
\hline & & Hsinchu & 26.9 & $121^{\circ} 00^{\prime} 22^{\prime \prime} \mathrm{E}$ & $24^{\circ} 49^{\prime} 48^{\prime \prime} \mathrm{N}$ \\
\hline & \multirow{2}{*}{ Mountain } & Anbu & 825.8 & $121^{\circ} 31^{\prime} 12^{\prime \prime} \mathrm{E}$ & $25^{\circ} 11^{\prime} 11^{\prime \prime} \mathrm{N}$ \\
\hline & & Zhuzihu & 607.1 & $121^{\circ} 32^{\prime} 11^{\prime \prime} \mathrm{E}$ & $25^{\circ} 09^{\prime} 54^{\prime \prime} \mathrm{N}$ \\
\hline \multirow{9}{*}{ West } & \multirow{6}{*}{ Plain } & Tainan & 40.8 & $120^{\circ} 12^{\prime} 17^{\prime \prime} \mathrm{E}$ & $22^{\circ} 59^{\prime} 36^{\prime \prime} \mathrm{N}$ \\
\hline & & Hengchun & 22.1 & $120^{\circ} 44^{\prime} 17^{\prime \prime} \mathrm{E}$ & $22^{\circ} 00^{\prime} 20^{\prime \prime} \mathrm{N}$ \\
\hline & & Kaohsiung & 2.3 & $120^{\circ} 18^{\prime} 29^{\prime \prime} \mathrm{E}$ & $22^{\circ} 34^{\prime} 04^{\prime \prime} \mathrm{N}$ \\
\hline & & Chiayi & 26.9 & $120^{\circ} 25^{\prime} 28^{\prime \prime} \mathrm{E}$ & $23^{\circ} 29^{\prime} 52^{\prime \prime} \mathrm{N}$ \\
\hline & & Taichung & 84.1 & $120^{\circ} 40^{\prime} 33^{\prime \prime} \mathrm{E}$ & $24^{\circ} 08^{\prime} 51^{\prime \prime} \mathrm{N}$ \\
\hline & & Wuqi & 31.73 & $120^{\circ} 30^{\prime} 54^{\prime \prime} \mathrm{E}$ & $24^{\circ} 15^{\prime} 31^{\prime \prime} \mathrm{N}$ \\
\hline & \multirow{3}{*}{ Mountain } & Sun Moon Lake & 1017.5 & $120^{\circ} 54^{\prime} 29^{\prime \prime} \mathrm{E}$ & $23^{\circ} 52^{\prime} 53^{\prime \prime} \mathrm{N}$ \\
\hline & & Yushan & 3844.8 & $120^{\circ} 57^{\prime} 06^{\prime \prime} \mathrm{E}$ & $23^{\circ} 29^{\prime} 21^{\prime \prime} \mathrm{N}$ \\
\hline & & Alishan & 2413.4 & $120^{\circ} 48^{\prime} 18^{\prime \prime} \mathrm{E}$ & $23^{\circ} 30^{\prime} 37^{\prime \prime} \mathrm{N}$ \\
\hline \multirow{4}{*}{ East } & \multirow{4}{*}{ Plain } & Dawu & 8.1 & $120^{\circ} 53^{\prime} 44^{\prime \prime} \mathrm{E}$ & $22^{\circ} 21^{\prime} 27^{\prime \prime} \mathrm{N}$ \\
\hline & & Chenggong & 33.5 & $121^{\circ} 21^{\prime} 55^{\prime \prime} \mathrm{E}$ & $23^{\circ} 05^{\prime} 57^{\prime \prime} \mathrm{N}$ \\
\hline & & Hualien & 16.0 & $121^{\circ} 36^{\prime} 18^{\prime \prime} \mathrm{E}$ & $23^{\circ} 58^{\prime} 37^{\prime \prime} \mathrm{N}$ \\
\hline & & Taitung & 9.0 & $121^{\circ} 08^{\prime} 48^{\prime \prime} \mathrm{E}$ & $22^{\circ} 45^{\prime} 15^{\prime \prime} \mathrm{N}$ \\
\hline
\end{tabular}

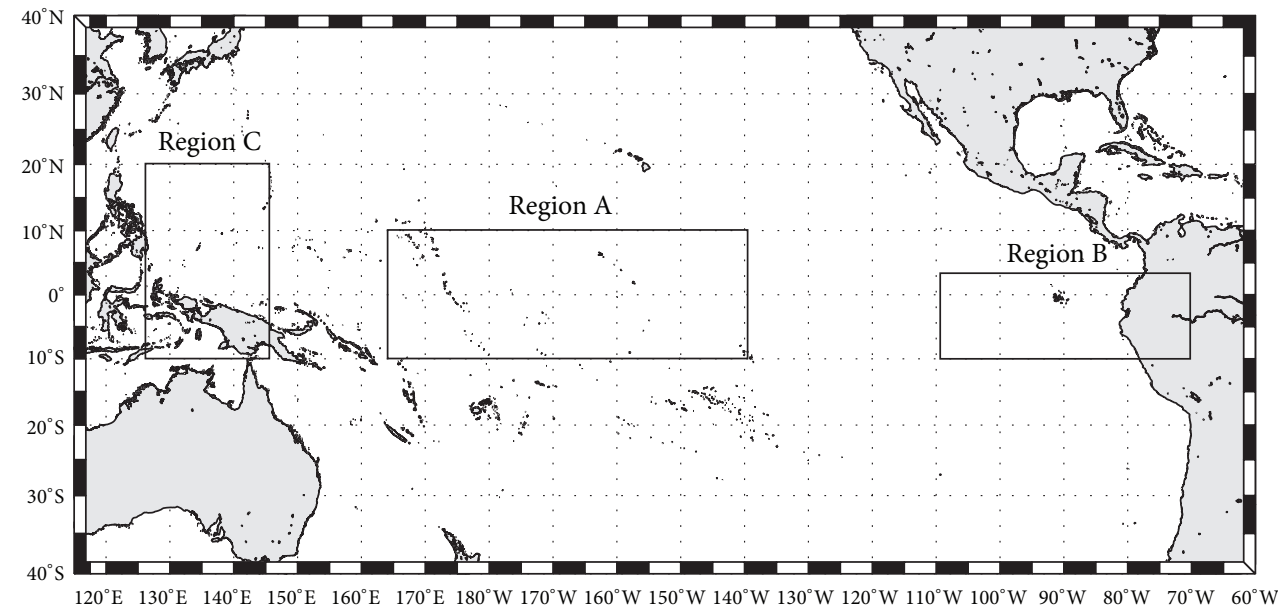

Figure 2: The regions for the definition of EMI.

rain period, one can see that correlation coefficients at all subareas are positive and higher than 0.7 during the canonical El Niño episode. Furthermore, the maximum correlation coefficient can be reached to 0.91 at western mountain subarea. The result is similar to that of Feng and Li [19] that the canonical El Niño enhances spring rainfall in Taiwan area.

Meiyu period, mostly cloudy to rainy, happens in May and June in Taiwan. The equilibrium strength forms a stationary front between the continental cold air mass and the Pacific warm air mass in southern China, Taiwan, and the Okinawa region. Low pressure disturbances often take place in these areas and bring abundant rainfall in Taiwan. In Figure 3, one can see that correlation coefficients at all subareas are positive and higher than 0.5. We consider the effects of Taiwan topography on this convective line intercept rainfall and enhance subsequent rainfall at western mountain subarea.

For summer rain period, the correlation coefficients are not significant at all subareas except for the eastern plain with the correlation coefficient of -0.62 . Since the summer rain in Taiwan is mainly affected by southwesterly monsoon and typhoon, the leeward side of monsoon, eastern plain, apparently has less rainfall related to the Niño 3.4 index. Less typhoon attacks Taiwan in El Niño episode also need to be considered. 


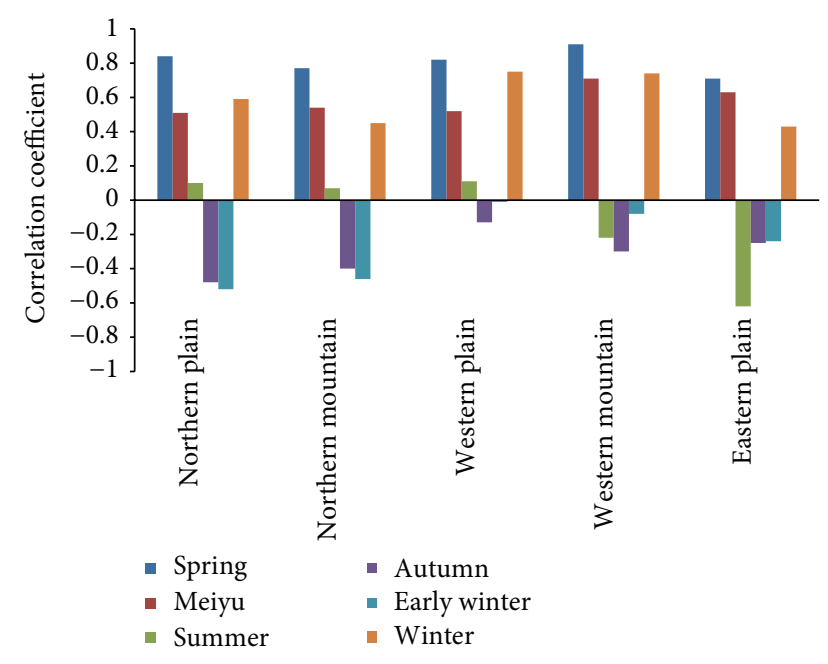

FIGURE 3: Correlation coefficients between rainfall anomaly and Niño 3.4 at five subareas during canonical El Niño episode.

In general, autumn climate resembles the early winter in northern Taiwan. During autumn and early winter, the rainfall is negative correlation with the intensity of El Niño at all subareas. However, only north area is significant where the correlation coefficient is -0.48 at plain subarea and -0.40 at mountain subarea in autumn rain period as well as -0.52 and -0.46 at plain and mountain subareas, respectively, in early winter rain period. The negative correlation coefficient displayed the negative relation between El Niño 3.4 index and rainfall anomaly. The intensity of El Niño enhances but rainfall diminishes more than others. Zhang et al. [25] noted the formation of time and location of the anticyclone near the Philippine Sea may affect the autumn rainfall over South China. The concept has the same idea by coincidence as Wang et al. [26] proposed that the canonical El Niño event may weaken the winter monsoon in East Asia, which responds to the graph shown in the early winter.

As shown in Figure 3, the winter rain period has positive correlation coefficients between rainfall anomaly and Niño 3.4 index at all subareas, especially in west region. At the moment, west region has been less affected by monsoon but more by the convergent cyclone. The correlation coefficient of 0.74 in the western plain during the El Niño episode displays the influence of El Niño starts from winter and then matures in the coming spring and summer.

To further explain possible processes of changing the rainfall, the wind field anomaly over the western Pacific associated with canonical El Niño is shown in Figure 4 which is sketched based on Figure 9 in Feng and Li [19]. During the canonical El Niño episodes, the warming sea surface water in the eastern Pacific results in asymmetric cyclonic anomalies on both sides of equator, with strong equatorial westerly anomalies. The southwesterly strengthens the moist transport to Taiwan from the South China Sea (SCS) and enhances the rainfalls in winter, spring, and Meiyu periods.

3.2. Influences during El Niño Modoki Episode. Figure 5 demonstrates correlation coefficients between rainfall anomaly and EMI at five subareas at six rain periods. Different from the canonical El Niño, El Niño Modoki is associated with strong anomalous warming in the central tropical Pacific and cooling in the eastern and western tropical Pacific. Associated with this distinct warming and cooling patterns, the teleconnections are very different from the canonical El Niño episode.

At the formation of El Niño Modoki, the Walker Circulation runs over the tropical Pacific and converges in East Asia. The relative cold sea surface temperature produces higher air pressure, and down-welling air produces sunny and less rainfall.

The influences of El Niño Modoki on rainfall in early winter and winter are similar to that in spring. In winter and spring periods, the negative correlation coefficients of rainfall anomaly and EMI index display the results of dry periods by the maximum correlation coefficient of -0.67 at western plain subarea.

For Meiyu, summer, and autumn rain periods, all correlation coefficients are positive and significant (higher than 0.5 ) except for the eastern plain. The results indicate that Meiyu, summer, and autumn rainfall increase in most of Taiwan during El Niño Modoki episodes, which happens to agree completely with the interpretation of C. Wang and X. Wang [23] that strong southwesterly caused by the anticyclone near the Philippine Sea brings entrained water vapor and enhances the rainfall in Taiwan during El Niño Modoki episodes.

Figure 6 is sketched based on Figure 9 in Feng and $\mathrm{Li}$ [19] showing the anomalous wind pattern over the western Pacific associated with El Nino Modoki. The northeasterly reduces moist transportation to Taiwan from SCS, resulting in suppressed rainfall from early winter to spring.

3.3. Influences during Canonical La Niña Episode. La Niña episode is characterized by anomalous cool water in the central-west equatorial Pacific with the negative Niño 3.4 index. It changes the intensity and distribution of rainfall, the patterns of sea level pressure and atmosphere circulation. La Niña episode displays considerable event-to-event variability and the overall effects tend to be less predictable than those for El Niño episodes.

In Figure 7, one can find that the rainfall over Taiwan is affected less obviously by La Niña episodes. Owing to the fact that the correlation coefficient displays the relations between rainfall anomaly and Niño 3.4 index, the positive index indicates less rainfall; however, the negative indicates more rainfall. The rainfall effects by La Niña seem not obvious, except for the summer rain period at northern mountain and autumn rain period at north and east regions. Less summer rainfall at northern mountain subarea is in response to the colder sea surface temperature and less typhoon which brings the major rainfall in Taiwan. Apparently, the summer rainfall brought by typhoon decreases in the windward side at northern mountain subarea; likewise, the rainfall increases in autumn with the coming of stronger northeast monsoon at north and east regions.

3.4. Influences during La Niña Modoki Episode. During La Niña Modoki episode, a cold anomaly arises in the central Pacific flanked by warmer anomalies on both sides of the 


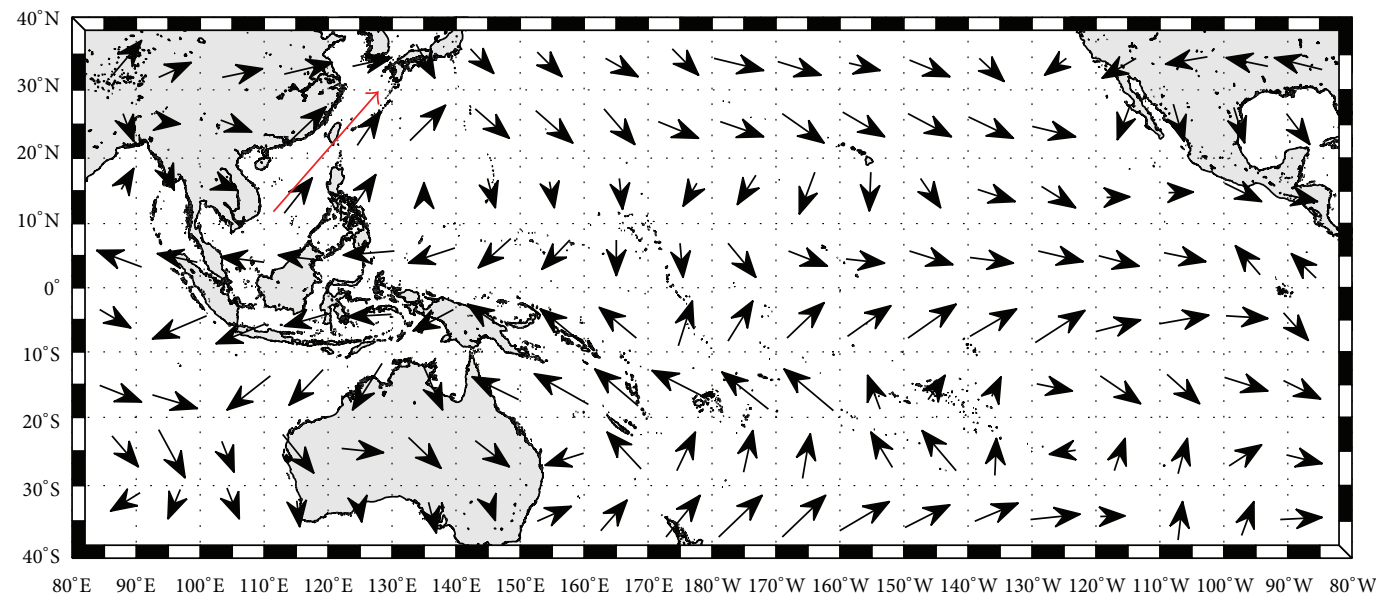

Figure 4: Anomalous patterns of wind vector over the Western Pacific during canonical El Nino episodes. The red arrow indicates the wind direction near Taiwan (sketched based on Feng and Li [19]).

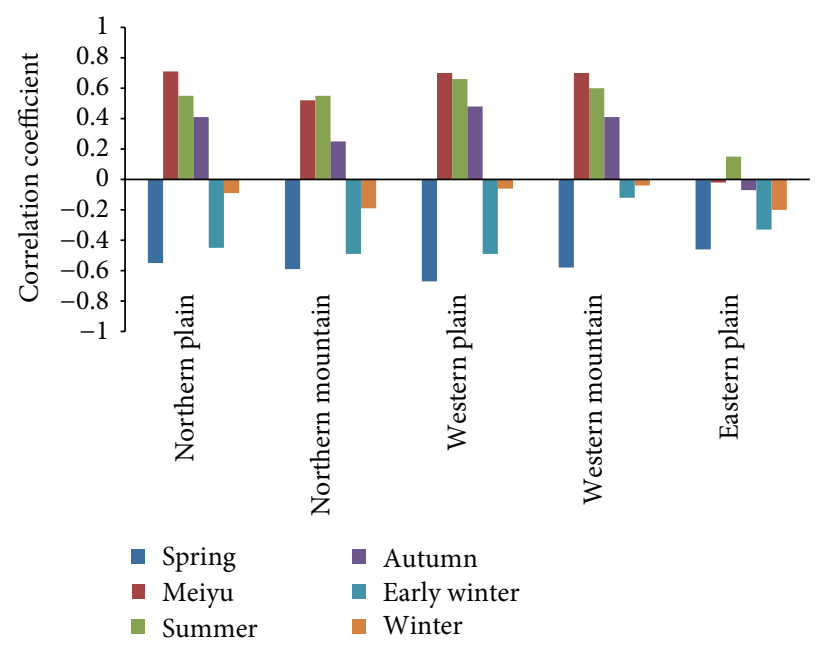

FIgURE 5: Correlation coefficients between rainfall anomaly and EMI at five subareas during El Niño Modoki episode.

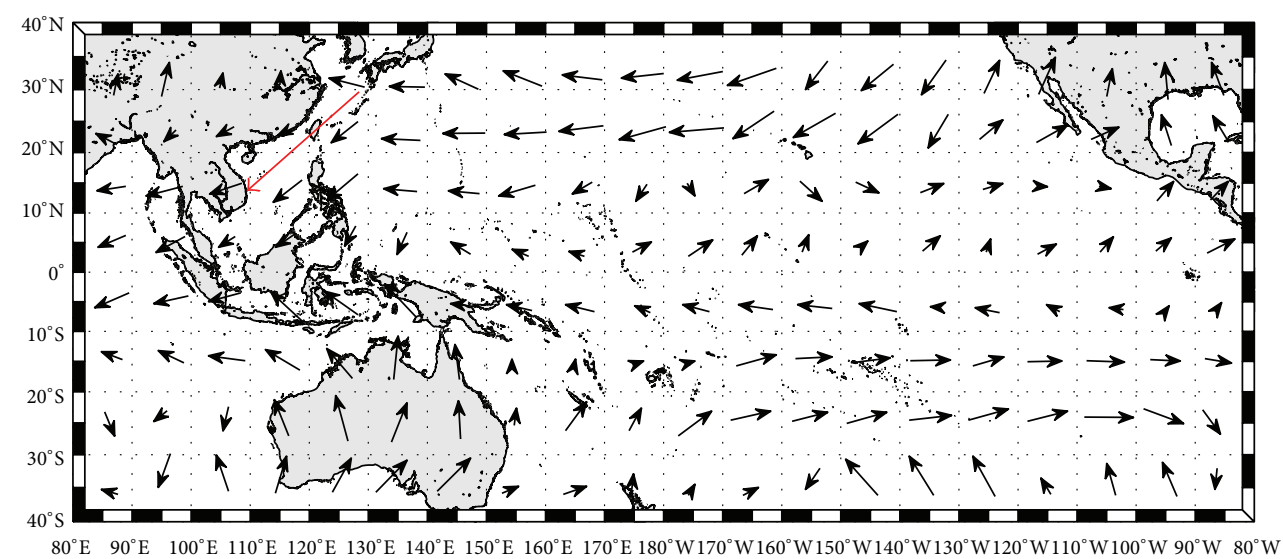

Figure 6: Anomalous patterns of wind vector over the Western Pacific during El Nino Modoki episode. The red arrow indicates the wind direction near Taiwan (sketched based on Feng and Li [19]). 


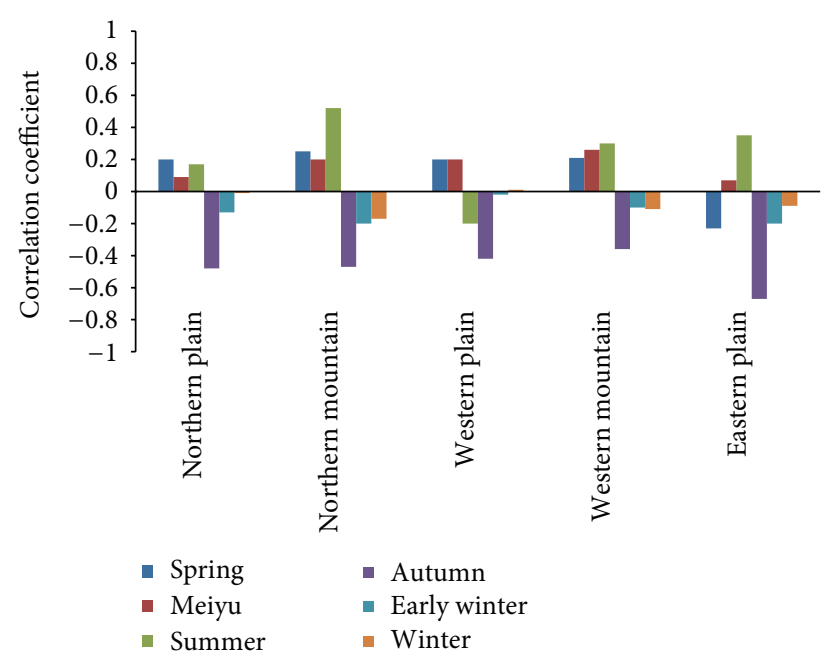

FIGURE 7: Correlation coefficients between rainfall anomaly and Niño 3.4 at five subareas during canonical La Niña episode.

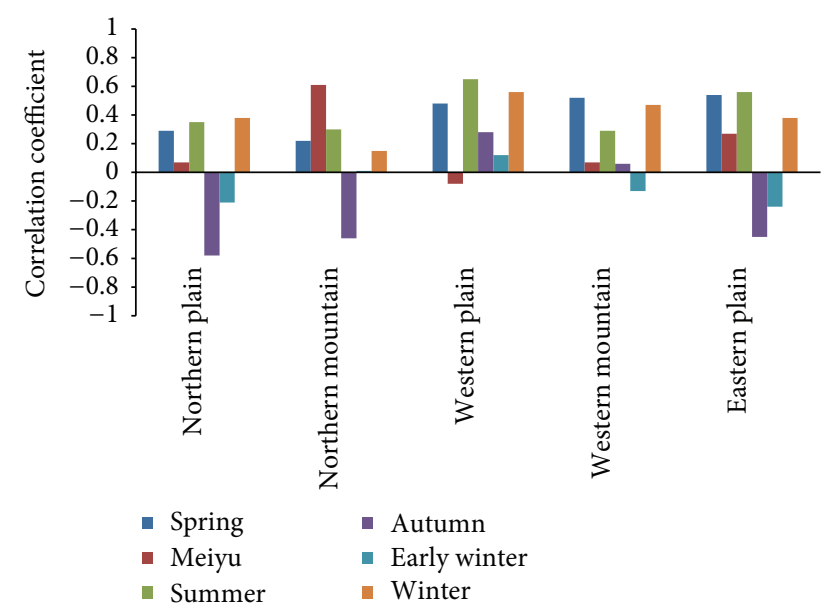

FIgURE 8: Correlation coefficients between rainfall anomaly and EMI at five subareas during La Niña Modoki episode.

basin. The air rises up in both sides of Pacific and sinks in the middle of Pacific, which makes the East Asia locates in a more rainfall condition. However, it is not the case shown in Taiwan.

In Figure 8, the positive correlation coefficient (higher than 0.5 ) suggests that the rainfall decreases significantly in spring at west and east Taiwan during La Niña Modoki episodes. A similar phenomenon can be also found in summer rain especially at western plain and eastern plain subareas.

For Meiyu period, obvious relationship is only at northern mountain with the correlation coefficient of 0.61 . Positive correlation coefficient means Meiyu decreasing during La Niña Modoki. In autumn rain period, significant negative correlation coefficients point out the rainfall increases at north and east regions, which are possibly influenced by the windward side of monsoon.

The rainfall during La Niña Modoki episode mostly looks descending. This is possibly affected by the shift of
Intertropical Convergent Zone (ITCZ). Previous studies have documented that the rainfall in equatorial regions depends on the presence of the ITCZ. A small variation in the position of the ITCZ can have a major effect on rainfall in certain regions [27, 28]. Dai and Wigley [29] used empirical orthogonal function analysis and showed patterns of ENSO induced precipitation. From the amplitude of principal component of precipitation in their study, one can find that there is no big change in both canonical La Niña and La Niña Modoki episodes. Somehow, Yuan and Yan [30] indicated that the changes of sea surface temperature of the two types of La Niña are not obvious. Compared to both, the atmosphere is more active during La Niña Modoki than that in canonical La Niña, which makes the correlation coefficient display apparently.

\section{Conclusions}

This study focuses on the influences of rainfall over Taiwan during two-type ENSO episodes. The rainfall data at 20 stations in Taiwan from 1980 to 2011 are used in this study. According to the geomorphology of Taiwan, we divide the study area into north, west, and east regions and further separate each region into plain and mountain subareas. The rainfall periods are separated by bimonthly and are defined as spring rain period (March and April), Meiyu period (May and June), summer rain period (July and August), autumn rain period (September and October), early winter rain period (November and December), and winter rain period (January and February). We also apply Nino 3.4 index and EMI to differentiate between canonical ENSO and ENSO Modoki episodes. The different patterns of rainfall distribution are associated with differences in regional sea surface temperature anomalies, regional circulation, and the patterns of ascending or descending air associated with Walker circulation over this region.

The major findings in this study are summarized as follows.

(1) The rainfall increases in Taiwan in northeast monsoon and Meiyu seasons during the canonical El Niño and the almost opposite feature occurs during the El Niño Modoki but its influence is less than that in canonical El Niño.

(2) The influence of canonical La Niña on rainfall is not obvious in Taiwan, except for autumn when the rainfall increases. A similar phenomenon is found during La Niña Modoki.

(3) The impacts of canonical La Niña and ENSO Modoki enhance rainfall obviously in autumn, while the impacts of ENSO Modoki dominate the rainfall in summer period.

(4) Relative to the two-type ENSO, canonical El Niño event affects rainfall over Taiwan predominately.

\section{Conflict of Interests}

The authors declare that there is no conflict of interests regarding the publication of this paper. 


\section{Acknowledgments}

The authors are grateful to the Data Bank For Atmospheric Project, Taiwan Typhoon and Flood Research Institute, National Applied Research Laboratories for the support of atmospheric research data. This work is partly supported by the Ministry of Science and Technology of Taiwan through grant MOST 103-2611-M019-006.

\section{References}

[1] S. G. H. Philander, "El Niño and La Niña," Journal of the Atmospheric Sciences, vol. 42, no. 23, pp. 2652-2662, 1985.

[2] C. F. Ropelewski and M. S. Halpert, "Precipitation patterns associated with the high index phase of the Southern Oscillation," Journal of Climate, vol. 2, no. 3, pp. 268-284, 1989.

[3] M. S. Halpert and C. F. Ropelewski, "Surface temperature patterns associated with the Southern Oscillation," Journal of Climate, vol. 5, no. 6, pp. 577-593, 1992.

[4] S. G. H. Philander, "El Niño southern oscillation phenomena," Nature, vol. 302, no. 5906, pp. 295-301, 1983.

[5] K. Ashok, S. K. Behera, S. A. Rao, H. Weng, and T. Yamagata, "El Niño Modoki and its possible teleconnection," Journal of Geophysical Research C: Oceans, vol. 112, no. 11, Article ID C11007, 2007.

[6] K. Ashok and T. Yamagata, "Climate change: the El Nĩo with a difference," Nature, vol. 461, no. 7263, pp. 481-484, 2009.

[7] J.-S. Kug, F.-F. Jin, and S.-I. An, "Two types of El Niño events: cold tongue El Niño and warm pool El Niño," Journal of Climate, vol. 22, no. 6, pp. 1499-1515, 2009.

[8] H.-Y. Kao and J.-Y. Yu, "Contrasting eastern-pacific and centralpacific types of ENSO," Journal of Climate, vol. 22, no. 3, pp. 615632, 2009.

[9] T. Shinoda, H. E. Hurlburt, and E. J. Metzger, "Anomalous tropical ocean circulation associated with La Niña Modoki," Journal of Geophysical Research C: Oceans, vol. 116, Article ID C12001, 2011.

[10] M. Roxy, N. Patil, K. Aparna, and K. Ashok, "Revisiting the Indian summer monsoon-ENSO links in the IPCC AR4 projections: a cautionary outlook," Global and Planetary Change, vol. 104, pp. 51-60, 2013.

[11] J. V. Ratnam, S. K. Behera, Y. Masumoto, K. Takahashi, and T. Yamagata, "Anomalous climatic conditions associated with the El Niño Modoki during boreal winter of 2009," Climate Dynamics, vol. 39, no. 1-2, pp. 227-238, 2012.

[12] S.-W. Yeh, J.-S. Kug, B. Dewitte, M.-H. Kwon, B. P. Kirtman, and F.-F. Jin, "El Niño in a changing climate," Nature, vol. 461, p. 515, 2009.

[13] J.-Y. Yu and H.-Y. Kao, "Decadal changes of ENSO persistence barrier in SST and ocean heat content indices: 1958-2001," Journal of Geophysical Research D: Atmospheres, vol. 112, no. 13, Article ID D13106, 2007.

[14] K. E. Trenberth and J. M. Caron, "The southern oscillation revisited: sea level pressures, surface temperatures, and precipitation," Journal of Climate, vol. 13, no. 24, pp. 4358-4365, 2000.

[15] R. Zhang and A. Sumi, "Moisture circulation over East Asia during El Niño episode in northern winter, spring and autumn," Journal of the Meteorological Society of Japan, vol. 80, no. 2, pp. 213-227, 2002.

[16] H. Weng, K. Ashok, S. K. Behera, S. A. Rao, and T. Yamagata, "Impacts of recent El Niño Modoki on dry/wet conditions in the Pacific rim during boreal summer," Climate Dynamics, vol. 29, no. 2-3, pp. 113-129, 2007.

[17] A. S. Taschetto, C. C. Ummenhofer, A. S. Gupta, and M. H. England, "Effect of anomalous warming in the central Pacific on the Australian monsoon," Geophysical Research Letters, vol. 36, no. 12, Article ID L12704, 2009.

[18] W. Cai and T. Cowan, "La Niña Modoki impacts Australia autumn rainfall variability," Geophysical Research Letters, vol. 36, no. 12, Article ID L12805, 2009.

[19] J. Feng and J. Li, "Influence of El Nio Modoki on spring rainfall over south China," Journal of Geophysical Research D: Atmospheres, vol. 116, no. 13, Article ID D13102, 2011.

[20] W. Zhang, F.-F. Jin, J. Li, H.-L. Ren, and J.-X. Zhao, “Differences in teleconnection over the North Pacific and rainfall shift over the USA associated with two types of El Niño during boreal autumn," Journal of the Meteorological Society of Japan, vol. 90, no. 4, pp. 535-552, 2012.

[21] M.-C. Yen and T.-C. Chen, "Seasonal variation of the rainfall over Taiwan," International Journal of Climatology, vol. 20, no. 7, pp. 803-809, 2000.

[22] J. Feng, W. Chen, C.-Y. Tam, and W. Zhou, "Different impacts of El Niño and El Niño Modoki on China rainfall in the decaying phases," International Journal of Climatology, vol. 31, no. 14, pp. 2091-2101, 2011.

[23] C. Wang and X. Wang, "El Niño modoki I and II by different impacts on rainfall in southern China and typhoon tracks," Journal of Climate, vol. 26, no. 4, pp. 1322-1338, 2013.

[24] C. H. Wang, L. A. Li, and W. C. Liu, "Some characteristics of the precipitation in Taiwan," in Biodersity and Terrestrial Ecosystem, C. I. Peng and C. H. Chou, Eds., Academia Sinica Monograph Series no. 14, pp. 343-354, Institute of Botany, 1994.

[25] W. Zhang, F.-F. Jin, J. Li, and H.-L. Ren, "Contrasting impacts of two-type El Niño over the western North Pacific during boreal autumn," Journal of the Meteorological Society of Japan, vol. 89, no. 5, pp. 563-569, 2011.

[26] B. Wang, R. Wu, and X. Fu, "Pacific-East Asian teleconnection: how does ENSO affect East Asian climate?" Journal of Climate, vol. 13, no. 9, pp. 1517-1536, 2000.

[27] Q. Zheng, X.-H. Yan, W. T. Liu, W. Tang, and D. Kurz, "Seasonal and interannual variability of atmospheric convergence zones in the tropical Pacific observed with ERS-1 scatterometer," Geophysical Research Letters, vol. 24, no. 3, pp. 261-263, 1997.

[28] T. Schneider, T. Bischoff, and G. H. Haug, "Migrations and dynamics of the intertropical convergence zone," Nature, vol. 513, no. 7516, pp. 45-53, 2014.

[29] A. Dai and T. M. L. Wigley, "Global patterns of ENSO-induced precipitation," Geophysical Research Letters, vol. 27, no. 9, pp. 1283-1286, 2000.

[30] Y. Yuan and H. M. Yan, "Different types of La Niña events and different responses of the tropical atmosphere," Chinese Science Bulletin, vol. 58, no. 3, pp. 406-415, 2013. 

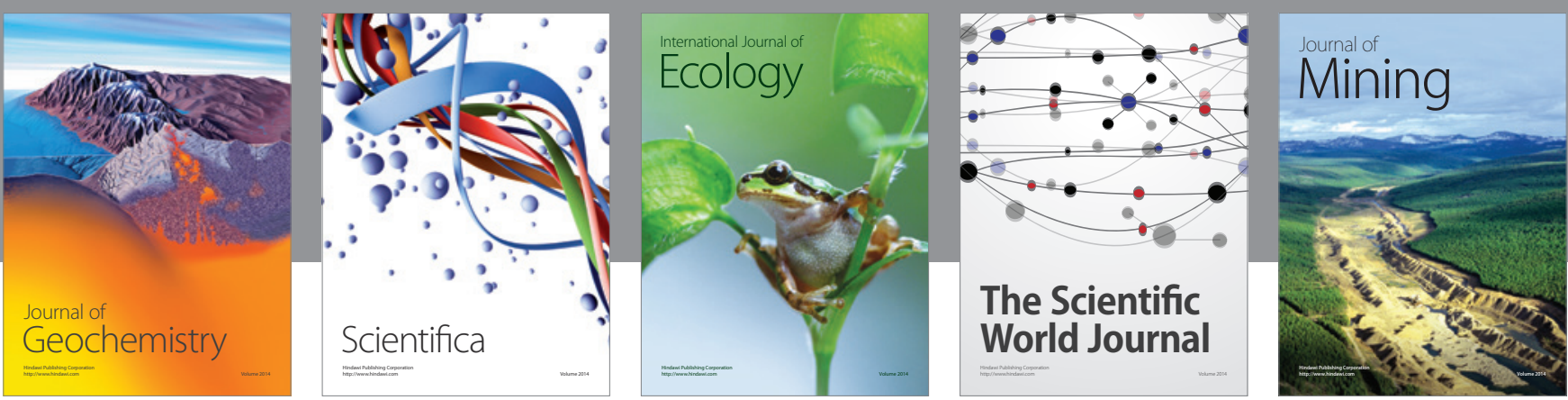

The Scientific World Journal
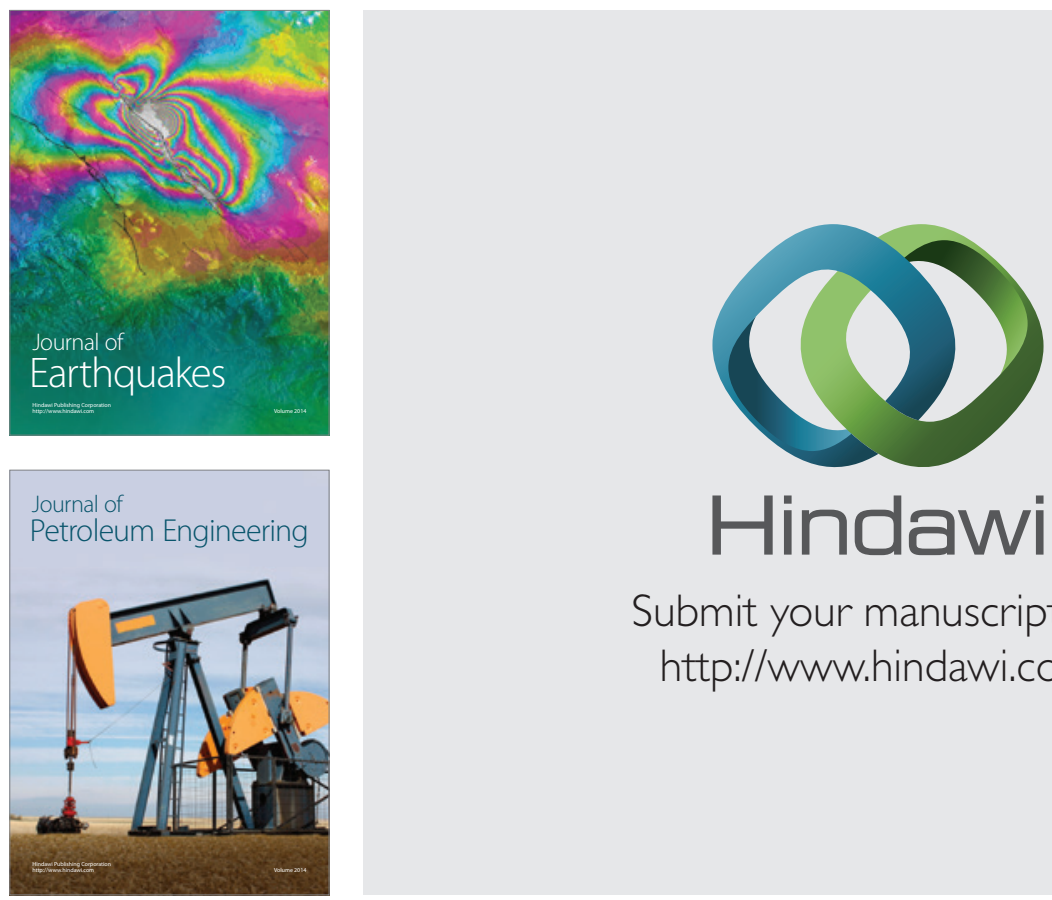

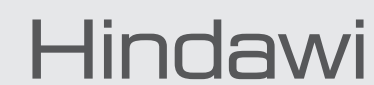

Submit your manuscripts at

http://www.hindawi.com
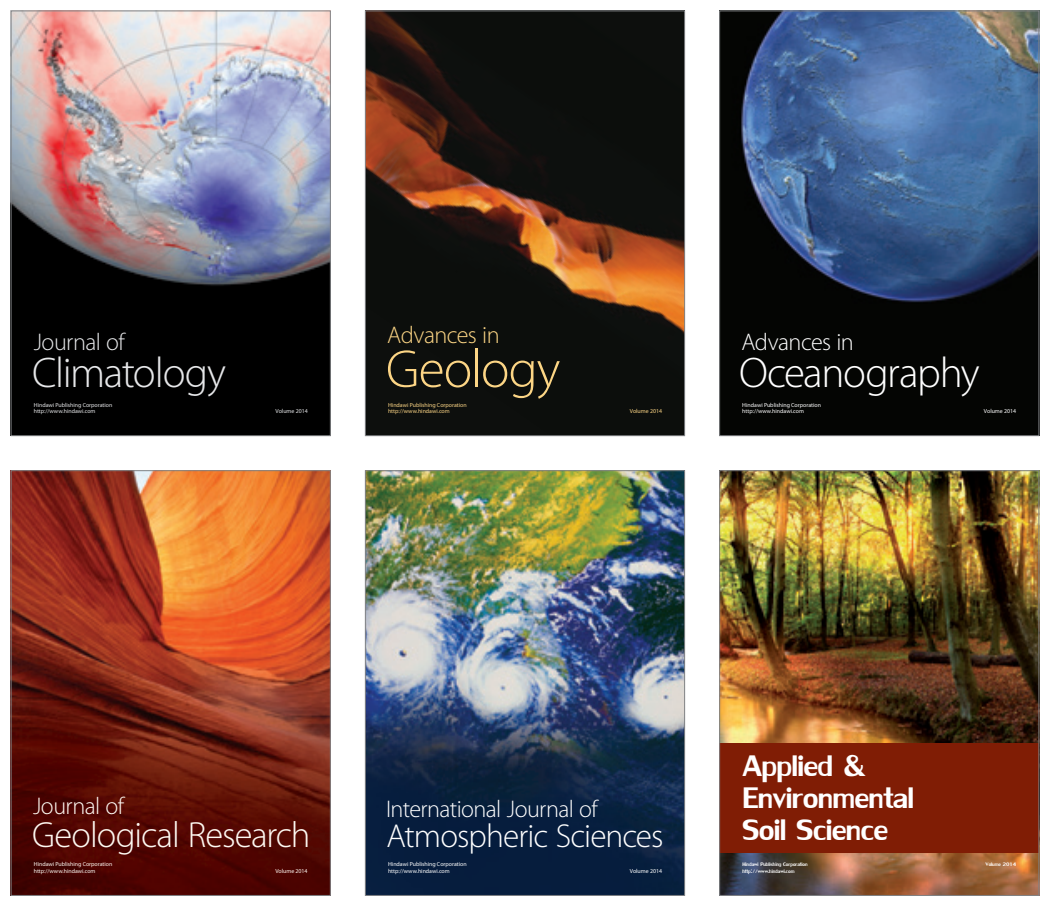
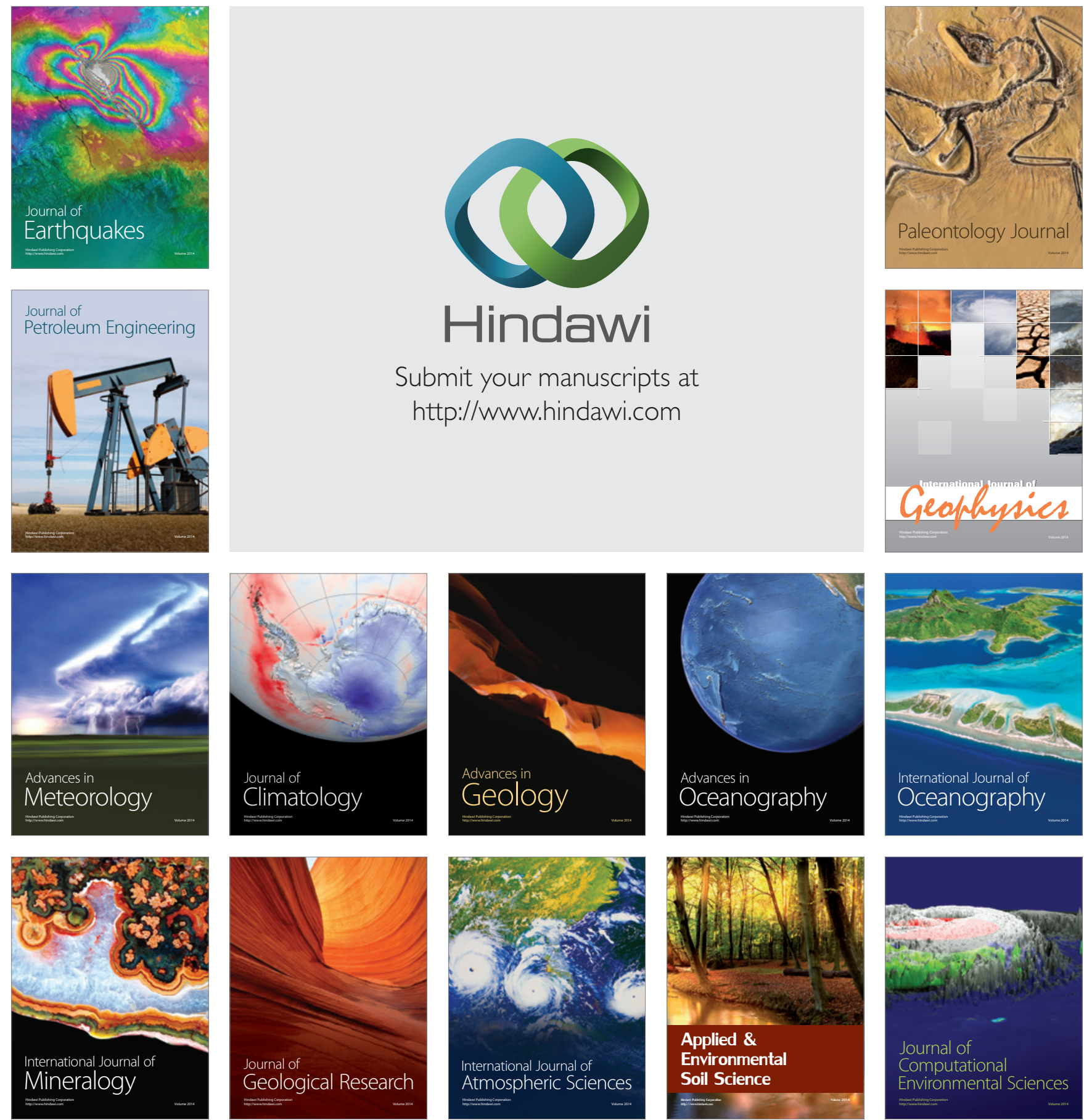